\title{
Anselm's Predicament: the Proslogion and Anti-intellectual Rhetoric in the Aftermath of the Berengarian Controversy
}

\section{Niskanen, Samu}

2021

Niskanen , S 2021, ' Anselm's Predicament: the Proslogion and Anti-intellectual Rhetoric in the Aftermath of the Berengarian Controversy ' , Journal of the History of Ideas , vol. 82 , no. 4 , pp. 547-568 . https://doi.org/10.1353/jhi.2021.0032

http://hdl.handle.net/10138/339493

https://doi.org/10.1353/jhi.2021.0032

acceptedVersion

Downloaded from Helda, University of Helsinki institutional repository.

This is an electronic reprint of the original article.

This reprint may differ from the original in pagination and typographic detail.

Please cite the original version. 


\section{Anselm's Predicament: the Proslogion and Anti-intellectual Rhetoric in the Aftermath of the Berengarian Controversy}

Monologion and Proslogion, the first two scholarly treatises of Anselm of Bec, later of Canterbury (†1109), set him at the heart of a learned debate. Completed in the late 1070s, both works met with criticism at first, such that Anselm was wary of disseminating them until, sometime between 1083 and 1085, he received an injunction from Archbishop Hugh of Lyon, papal legate to Gaul, that the works be properly circulated under their author's name. The present essay focuses on Anselm's anxieties before he was given the shelter of Hugh's mandate. While Anselm's troubles with the Monologion have often been commented on, the centre of attention here is the Proslogion, the work that delivers the famous ontological argument, one of the most influential single lines of speculative reasoning ever written. What follows seeks to place the Proslogion in the contexts of the Monologion's initial reception and, more importantly, of a wave of anti-intellectual rhetoric that was current across Normandy.

Anti-intellectual rhetoric, a key concept here, requires some brief clarification. Throughout this essay, the phrase anti-intellectual rhetoric is used to denote professed hostility, feigned or genuine, to the act of expounding faith with recourse to reasoning rather than auctoritates, or authoritative proofs, from the Bible, patristic writings, canon law, and other pertinent texts. Such rhetoric had already found its way into erudite Christian discussion in the patristic period. ${ }^{1}$

\footnotetext{
* This text is an unedited pre-publication draft. The essay will be published in the Journal of the History of Ideas. This project has received funding from the European Union's Horizon 2020 research and innovation programme under grant agreement No 716538 (MedPub). I thank Dr James Willoughby, Dr Toivo Holopainen, Prof. Bernd Goebel, Dr Sigbjørn Sønnesyn, and the anonymous reviewers for their comments. I am likewise indebted to the participants of the 2018 conference St. Anselm of Aosta, Bec and Canterbury: Theologian, Statesman,
} 
Particularly upon encountering pagan philosophy, several Fathers, who used dialectical tools at their convenience, pronounced their dissatisfaction with rationalistic argumentation advanced by their opponents. Medieval authors applied the same strategy. In the eleventh century, for instance, monastic and papal reformers such as Otloh of St Emmeram, Peter Damian, and Manegold of Lautenbach alleged that their adversaries went astray due to their reliance on reasoning rather than on the Bible and Fathers. There was a degree of rhetorical gesturing in such utterances; those three writers, like many others making similar allegations, were content to use dialectical approaches in their own works. ${ }^{2}$ The rhetorical aspect manifested itself also in the recurrent citation of a body of patristic and biblical comment, of which Sections II and III offer instances. Such anti-intellectual rhetoric was often related to tensions arising from two interconnected trends in the eleventh century: the increasing role of the liberal arts in education and the increasing importance of cathedral schools. ${ }^{3}$ The circumstances provoked (over)statements, especially by monastic writers, that certain masters associated with cathedral schools relied excessively on reasoning. ${ }^{4} \mathrm{~A}$ case in point is the Berengarian controversy over the Eucharist, whose conclusion coincided with Anselm's composition of the Proslogion.

This essay's central assertion is that to read the Proslogion in context, one must also consider the cause against Berengar, which was a major affair in Normandy. I shall argue that the Proslogion

\footnotetext{
Administrator, Teacher in Houston (Texas) and the Medieval Publishing Seminar at the University of Helsinki. Any remaining errors are my own.

${ }^{1}$ Mark Edwards, Aristotle and Early Christian Thought (London: Routledge, 2019), 38-54.

${ }^{2}$ Irven Resnick, "Attitudes towards Philosophy and Dialectic during the Gregorian Reform," Journal of Religious History 16 (1990): 115-25, at 116.

${ }^{3}$ C. Stephen Jaeger, Envy of Angels: Cathedral Schools and Social Ideals in Medieval Europe, 950-1200 (Philadelphia: University of Pennsylvania Press, 1994), esp. 217-22.

${ }^{4}$ A full-scale invective is Manegold of Lautenbach's Liber contra Wolfelmum. His opponent was probably associated with the cathedral school of Cologne, and was not abbot of Brauweiler as once thought; Peter Dronke, The Spell of Calcidus: Platonic Concepts and Images in the Medieval West (Florence: Sismel, 2008), 88 and 106.
} 
responds to contemporary denunciations of the rationalistic method, a constant theme in polemics against Berengar and the gist of criticisms that had been levelled against the Monologion. Three discussions will deliver this proposition. Section I maintains that upon composing and releasing the Proslogion, Anselm faced a predicament. Section II contextualizes his predicament as ensuing from misgivings about the validity of rationalistic inquiry into faith, which were fanned by anti-intellectual rhetoric against Berengar. Prompted by these discussions, Section III proposes that one function of the Proslogion's epistemological emphases and its much-admired prayer-like literary idiom was to pre-empt any censure; and that after his predicament had been resolved, Anselm supplemented the Proslogion with devices to underscore its rationalistic aspect.

\section{Anonymity and endorsement}

To understand Anselm's situation when composing the Proslogion, we must briefly examine the Monologion, his first scholarly treatise. He wrote it at the abbey of Bec in Normandy in 1077 or thereabouts. It was first titled Exemplum meditandi de ratione fidei, and only later Monologion. (For convenience here, I will refer to the work as Monologion throughout.) The work explores such profound theological topics as God's essence, so that, as stated in its prologue, nothing is "argued on the basis of the authority of Scripture" and "the constraints of reason [...] with downto-earth dialectic" prove the conclusions. ${ }^{5}$ While the Monologion occasionally alludes to biblical

\footnotetext{
${ }^{5}$ Anselm of Canterbury, The Major Works, trans. Brian Davies and Gillian Evans (Oxford: Oxford University Press, 1998), 5; Sancti Anselmi opera, ed. Franciscus Schmitt [hereafter SAO], 6 vols. (Seckau, Rome, Edinburgh: 193861), $1: 7$.
} 
and patristic sources, its approach is an exclusively rationalistic one. ${ }^{6}$ Anselm argued from reason rather than authorities. ${ }^{7}$ Before publishing, he submitted the work to the censorship of Archbishop Lanfranc of Canterbury $(\dagger 1089)$, who had been his teacher and predecessor as prior at Bec. ${ }^{8}$ Lanfranc's response does not survive, but from Anselm's subsequent letter to him it is clear that the archbishop had not approved. Suspicious of purely rationalistic inquiry, Lanfranc had recommended Anselm to cite "divine proofs" ("diuinis auctoritatibus"). ${ }^{9}$ At any rate, Lanfranc did finally accept Anselm's justifications, as attested by the dedicatory letter prefixed to the Monologion. Addressed to Lanfranc, it is an implicit proof of his endorsement. For it is inconceivable that Anselm would have inserted the letter without approval by the archbishop, his former master. Soon after, in 1077 or 1078, Abbot Rainald, perhaps of Saint-Cyprien at Poitiers, requested a copy of the treatise. Anselm complied, but without much enthusiasm; for he had "already suffered by the too-rushed judgements" about the work. ${ }^{10}$ Anselm was circulating his first learned treatise only reluctantly. ${ }^{11}$

He composed his next treatise, first called Fides quaerens intellectum but later rechristened Proslogion, soon after the first, either in 1077 or 1078. (Again, the work will be called Proslogion for the sake of convenience.) In a subsequently inserted preface, Anselm explained

\footnotetext{
${ }^{6}$ For his biblical exegesis, see Giles Gasper, "Between Dialectic and Sacred Scripture: Anselm of Canterbury and the Bible," Prayer and Thought in Monastic Tradition: Essays in Honour of Benedicta Ward, ed. Santha Bhattacharji, Rowan Williams, and Dominic Mattos (London: Bloomsbury, 2014), 181-96.

${ }^{7}$ For scholarship on Anselm's method, see bibliographies in Richard Campbell, Rethinking Anselm's Arguments, and Toivo Holopainen, Historical Study of Anselm's Proslogion: Argument, Devotion and Rhetoric (Leiden: Brill, 2018 and 2020 respectively).

${ }^{8}$ Letters of Anselm, Archbishop of Canterbury, ed. Samu Niskanen [henceforth Ep and cited by letter and page number] (Oxford: Oxford University Press, 2019), 63:186-87.

${ }^{9}$ Ep, 68:198-201.

${ }^{10} \mathrm{Ep}, 74: 214-15$.

${ }^{11}$ Richard Sharpe, "Anselm as Author: Publishing in the Late Eleventh Century," Journal of Medieval Latin 19 (2009): 1-87, at 18-19, 23.
} 
that the work proposed one argument, demonstrating God's existence and certain of his essential qualities. ${ }^{12}$ The foundation in question is now known as the ontological argument. Eadmer, a member of Anselm's household at Canterbury and eventually his biographer, was so impressed that he recounted the argument's genesis in his Vita Anselmi. Anselm drafted his argument on wax tablets. These were clandestinely taken away and never recovered. He wrote another draft, again on wax tablets. These were found smashed on the floor the next day. ${ }^{13}$ The two instances embodied repeated sabotage, first theft then destruction. A clandestine party within the cloister was attempting to halt the process of composition. Such onslaughts were rare, but not unparalleled in monastic milieux, as has been recently pointed out. An associate of Lawrence of Durham (†1154), envious of his success, stole his drafts. Disparaging Renier of Liège’s (†1188) musical compositions as dangerous frivolity, a monk of his house mutilated his drafts. ${ }^{14}$ The attack at Bec must have been bred by suspicions similar to, although more impassioned than, those Lanfranc had held about the Monologion. For the Proslogion bears but one single aspect that could have been considered threatening: Anselm's rationalistic method. A majority of Bec's monks stood by Anselm, their prior. Nonetheless, the assault on his drafts testified that a faction was present that espoused the more traditional views associated with Archbishop Lanfranc, the former master, and founder, of Bec's school. Such disharmony might explain implicit assurances by Anselm and Eadmer that the Monologion and Proslogion respectively promoted no discord. In the prologue to the Monologion Anselm gave the assurance that his brethren had commissioned its method of inquiry. ${ }^{15}$ Given how persistently his treatises argue from reason,

\footnotetext{
12 SAO, 1:93.

${ }^{13}$ Eadmer, Vita S. Anselmi, ed. Richard Southern (Oxford: Oxford University Press, 1972), 30-31.

${ }^{14}$ Giles Gasper, "Envy, Jealousy, and the Boundaries of Orthodoxy: Anselm of Canterbury and the Genesis of the Proslogion," Viator 41 (2010): 45-68, at 53-54.

15 SAO, 1:7.
} 
one wonders whether he was perhaps overstating his brethren's impact on the work. ${ }^{16}$ Eadmer, who was silent about incentives behind the assault on drafts towards the Proslogion, stressed that Anselm received the ontological argument when "the grace of God illuminated his heart." ${ }^{17}$ A divinely inspired work should offend none among the faithful.

Anselm circulated the Proslogion at first with restraint, as recently observed. ${ }^{18}$ The evidence comes from the preface which he furnished the work with when he published it together with the Monologion, sometime between 1083 and 1085. The preface remarked that the primary dissemination of the two treatises was under provisional titles (those mentioned above) and without Anselm's name at their head; that he only signed them at the request of Hugh of Lyon acting under papal mandate; and that at that point Anselm retitled them. ${ }^{19}$ The implication, certainly intended, was that the anonymous initial dissemination of the Monologion and Proslogion had been a provisional arrangement, something less than full publication under Hugh's auspices. Evidence from manuscripts provides that outline with fresh details.

Our only manuscript known to preserve the Monologion under its first title, Exemplum meditandi de ratione fidei, is Paris, $\mathrm{BnF}$, lat $13413 .^{20}$ It dates from the first half of the twelfth century and comes from the Norman abbey of Sées, with which Anselm was well connected. ${ }^{21}$ The said title suggests descent from a lost exemplar that preceded the retitling and, thus, Hugh's injunction.

\footnotetext{
${ }^{16}$ Gasper, "Envy, Jealousy," 62-63.

${ }^{17}$ Eadmer, Vita Anselmi, 30.

${ }^{18}$ Sharpe, “Anselm as Author," 16-19. The present discussion follows Sharpe's conceptualization (pp. 1, 15, and 17) of medieval publishing as an act by which writers identified themselves in contrast to anonymous release.

${ }^{19}$ SAO, 1:93-94. The date-frame derives from Hugh's designations as archbishop and papal legate. For his career, see Kriston Rennie, Law and Practice in the Age of Reform: The Legatine Work of Hugh of Die (1073-1106) (Turnhout: Brepols, 2010), 23-52.

${ }^{20}$ Fo. 5v.

${ }^{21}$ Ep, $115: 338$ and 136:392.
} 
Significantly, the book also includes the above-mentioned dedicatory letter to Lanfranc, which implies his pre-publication endorsement. The letter identifies the author of the following treatise as "frater Anselmus Beccensis." Anselm features prominently by name on the first folio as a result. The Monologion's first circulation as witnessed by the Sées manuscript was not an anonymous affair in the strict sense. The same is suggested by Anselm's instructions on how to issue the work, given at the same point that he sent it to Lanfranc for inspection. The arrangement was clearly for publication under his own name. ${ }^{22}$ Six manuscripts transmit the Proslogion under its provisional title, Fides quaerens intellectum..$^{23}$ They are too far removed from the original in time and place to verify whether or not Anselm had signed the work before he retitled it. Yet, their unambiguous testimony is that contrary to the Monologion, the Proslogion as circulated before Hugh's injunction did not include a proem, which would have disclosed the author's identity. We must assume, then, that Anselm's assertion of anonymity applied chiefly to the Proslogion, rather than the Monologion.

By Anselm's own account, Hugh's command was the crux of why he republished the Monologion and Proslogion together. Hugh, more than anyone else (maxime), had urged him to sign the treatises. In so doing, Hugh had acted in his capacity as papal legate. The detail was clearly of significance, for Anselm mentioned it twice within a single sentence. ${ }^{24}$ Hugh's injunction was in essence an endorsement that Anselm's rationalistic approach enjoyed "apostolica"— that is, papal—sanction. Because, on the evidence of the Sées manuscript, the Monologion by then boasted Lanfranc's implicit commendation, so the dominant concern may

\footnotetext{
${ }^{22} \mathrm{Ep}, 65: 192$.

${ }^{23}$ London, BL, Harley 203; Paris, BnF, lat. 16364; Vatican, BAV, Barb. lat. 520; Berlin, SBB-PK, Hamilton 28; Assisi, Biblioteca del Sacro Convento, Assisi Com. 92; Oxford, Balliol College, 221.

${ }^{24} S A O, 1: 94-95$.
} 
again have been the Proslogion, the object of the violent in-house assault at Bec. Another hint is visible in that having completed the Proslogion, Anselm paused his career as a theological author for at least five years, until Hugh's intervention..$^{25}$ It is true that he was preferred to the abbacy in 1078, but new burdens of office may not entirely account for this fallow period since he apparently found the time to write his only secular treatise, Quomodo grammaticus, during those years before Hugh's endorsement. ${ }^{26}$ The hesitant circulation of the Monologion, the Proslogion's anonymous release, and after that, silence, has the appearance of confidence in decline. Hugh's injunction, unparalleled as a legatine act, hints at the same thing. His decision to intervene in his apostolic capacity implies that a genuine predicament, rather than monastic humility, prevented Anselm from publishing under his own name. Significantly, our evidence does not suggest that he had released his earlier writings, his prayers, anonymously. Known as their author even outside Normandy, Anselm readily promoted them not only to associates, but also third parties such as Adeliza, a royal lady. ${ }^{27}$ The Proslogion's anonymous release contrasts with that pattern.

\section{The Berengarian controversy}

Berengar of Tours reopened learned debate on the Eucharist in the late 1040s after a hiatus since the tenth century. He was a secular teacher, affiliated to the cathedrals of Tours and Angers. He maintained a symbolistic view that the consecrated bread and wine signify the body and blood of Christ. His critics, who were to prevail, asserted that the bread and wine constitute the body and

\footnotetext{
${ }^{25}$ Sharpe, "Anselm as author," 20-21.

${ }^{26}$ Ep, 88:258; Sharpe, "Anselm as author," 22.

${ }^{27}$ Ep, 20:66; 61:180; 141:404.
} 
blood of Christ in actuality. Rome soon engaged in the controversy..$^{28}$ The first official papal discussions on the subject took place in Pope Leo IX's synods of 1050 in the Lateran and at Vercelli, in May and September respectively. Exchanges continued between Berengar and papal circles. The final confrontations took place during his year-long sojourn at Rome from the turn of 1077. Two assemblies convened by Pope Gregory VII discussed the affair, with the result that Berengar was forced to publicly recant his teaching. The pope also demanded that Berengar retire and keep silence on the matter. Berengar's career as teacher was over and his reputation left in ruins.

His teaching was debated with particular passion in Normandy, as testified by unique synodal regulation, to be discussed below, and the unparalleled scope of written polemics against him. Of the five authors who composed full-length treatises on the subject before Berengar's downfall, Lanfranc, Guitmund, and Durand of Troarn were Normans. (The remaining two were the Frenchman, Hugh of Langres and the Italian, Alberic of Monte Cassino.) According to a modern commentator, the Norman debate was "a fight to the finish," contrasting with "occasional civil remonstrances" elsewhere in France. ${ }^{29}$ It has been recently argued that such divergent intensities ensued largely from political allegiances. Berengar's patron was the powerful Count Geoffrey II of Anjou ( $\dagger 1060)$, whom he served as an articulate defender. Proximity to the count allowed Berengar's voice to be heard, but it also identified him with Anjou's cause in the course of a prolonged conflict between Normandy and Anjou over the territory of Maine. As a result, the denunciation of his teaching became expedient in circles whose loyalties were to the duke of

\footnotetext{
${ }^{28}$ See H. E. J. Cowdrey, "The Papacy and the Berengarian Controversy," in Auctoritas und Ratio: Studien zu Berengar von Tours, ed. Peter Ganz, R. Huygens, and Friedrich Niewöhner (Wiesbaden: Otto Harrassowitz, 1990), 109-38.

${ }^{29}$ Margaret Gibson, "Letters and Charters Relating to Berengar of Tours," Auctoritas und Ratio, 5-23, at 14-15.
} 
Normandy. ${ }^{30}$ Berengar's post-mortem reputation neatly captures the divergence of political affiliation. Authors from central France eulogized him, whereas William of Malmesbury, who drew on Norman reports and rumours, considered Berengar an arch-heretic. ${ }^{31}$ What follows is not a comprehensive account of the Norman commentary on Berengar; scholarship on the subject is abundant. The aim here is solely to demonstrate that in the province of Rouen, which largely coincided with the duchy of Normandy, the discussion of Berengar's teaching was a sustained affair inciting anti-intellectual rhetoric; and that Anselm's brethren were well informed on the controversy.

Berengar stimulated the discussion in Normandy in person. In 1050 he entered the court of Duke William the Bastard $(\dagger 1087)$ in order to win support for his Eucharistic views. William had an ecclesiastical assembly convened to deliberate the matter. The outcome was a defeat for Berengar. ${ }^{32}$ The debate was not concluded there but was soon carried on in writing, so that five expositions, three major treatises, and two shorter comments by Norman authors survive to date. The tone was thoroughly anti-Berengarian.

One of Berengar's Norman detractors was the aforementioned Lanfranc, prior of Bec from $c$. 1045 to 1063 and subsequently the first abbot of St Étienne at Caen and then archbishop of Canterbury. Some months before Duke William's conference of 1050, Berengar sent Lanfranc a

\footnotetext{
${ }^{30}$ Constant Mews and Clare Monagle, "Theological Dispute and the Conciliar Process 1050-1150. From Berengar of Tours to Gilbert of Poitiers," in Ecclesia disputans. Die Konfliktpraxis vormoderner Synoden zwischen Religion und Politik, ed. Christoph Dartmann, Andreas Pietsch, and Sita Steckel (München: De Gruyter, 2015), 127-57, at 129-40.

${ }^{31}$ Les oeuvres poétiques de Baudri de Bourgueil (1046-1130), ed. P. Abrahams (Paris: Champion, 1926), 82; Hildebert of Lavardin, Carmina Minora, ed. A. Scott (Leipzig: Teubner, 1969), 7-9; William of Malmesbury, Gesta Regum Anglorum, ed. R. Mynors, R. Thomson, and M. Winterbottom (Oxford: Oxford University Press, 1998$), 519$. 32 Durand of Troarn, Liber de corpore et sanguine Christi, Patrologia Latina 149:1422A.
} 
letter to enquire about his views on the Eucharist. ${ }^{33}$ Reaching Lanfranc in Rome, where he was in company with Pope Leo IX, the letter was read to the Lateran Synod in May 1050. At the request of the pope, Lanfranc proved his allegiance to catholic doctrine in front of the assembled clergy. Discussion on Berengar's teaching was resumed at the Synod of Vercelli in September, apparently with comments by Lanfranc, whom the pope had invited to attend..$^{34}$ Lanfranc's subsequent involvement is observable only imperfectly. We do not know, for instance, whether or not he attended the legatine council at Tours in 1054 or the Easter Synod of 1059, at which Pope Nicholas II formally condemned Berengar. Lanfranc's main contribution to the controversy was a tract, De corpore et sanguine Domini, published sometime during his abbacy at Caen from 1063 to 1070 . The work took dialogue form, with Lanfranc and Berengar as the interlocutors. The dichotomy between the two was emphasized by the assertion that whereas the former preferred sacrae auctoritates, the latter built on dialecticae rationes ${ }^{35}$ Such a characterization was biased and misleading, as Berengar himself explicitly pointed out in his response to Lanfranc. ${ }^{36}$ While prepared, by his own admission, to employ dialectical apparatus, Berengar did not build on reason alone. Indeed, recent scholarship has observed that he was influenced more profoundly by patristic and biblical readings ${ }^{37}$ Claiming that Berengar's approach was a

\footnotetext{
${ }^{33}$ Berengar, Epistola ad Lanfrancum, in R. Huygens, "Textes latins du XI ${ }^{\mathrm{e}}$ au XIII ${ }^{\mathrm{e}}$ siècle," Studi Medievali 8 (1967): 451-503, at 456.

${ }^{34}$ Lanfranc, De corpore et sanguine Domini, Patrologia Latina 150:413. For translation, see Mark G. Vaillancourt, Lanfranc of Canterbury On the Body and Blood of the Lord and Guitmund of Aversa On the Truth of the Body and Blood of Christ in the Eucharist (Washington, D.C.: The Catholic University of America Press, 2009), 36-8. ${ }^{35}$ Lanfranc, De corpore, Patrologia Latina 150:416D-417A, Vaillancourt, Lanfranc and Guitmund, 43-44. ${ }^{36}$ Berengar, Rescriptum contra Lanfrannum, ed. R. Huygens, Corpus Christianorum: Continuatio Mediaevalis 84 (Turnhout: Brepols, 1988), 85.

${ }^{37}$ Henry Chadwick, "Symbol and Reality: Berengar and the Appeal to the Fathers," Auctoritas und Ratio, 25-45, at 35; Charles Radding, "The Geography of Learning in Early Eleventh-century Europe: Lanfranc of Bec and Berengar of Tours Revisited," Bullettino dell'Istituto storico italiano per il Medioevo e Archivio muratoriano, 98 (1992): 145-72, at 168; Holopainen, Historical Study, 120-22. These rejected previous views that Berengar was foremost a dialectician; cf. J. Endres, "Die Dialektiker und ihre Gegner im 11. Jahrhundert," Philosophisches Jahrbuch 19 (1906): 20-33.
} 
disproportionately rationalistic one, Lanfranc sought to undermine his position by way of character assassination.

In another context, Lanfranc, who had earned fame as an early proponent of the liberal arts in northern Europe, noted that he avoided using the tools of that trade in biblical exegesis. ${ }^{38}$ This policy, he explained, resulted from the fact that dialectical reasoning about the mysteries of the faith provoked protest among those who had not mastered the method. ${ }^{39}$ He was not the only one to have observed this; Anselm made the same remark in a letter datable to the 1070s. Having delivered a rationalistic solution as to how to deal with lapsed clergy, Anselm referred to pertinent papal judgements for the benefit of those who would accept no assertion "other than by the authority of Scripture." ${ }^{40}$ The implication is that some of the readers available to Lanfranc and Anselm felt apprehensive about argument from reason in theological domains. Such circumstances would account for Lanfranc's distorted description of Berengar's approach.

Lanfranc's strategy was a well-established one. As mentioned above, monastic authors of the day resorted to similar rhetoric to overcome their enemies, often associated with cathedral schools as was Berengar. All known Norman polemicists were monks and they tapped into the antiintellectual trope to affirm that Berengar's reasoning was a repudiation of faith. In demonstration, I quote Anastasius the monk $(\dagger c .1085)$ and Abbot John of Fécamp $(\dagger 1079)$, whose anti-Berengarian pronouncements have attracted less attention than those of the other

\footnotetext{
${ }^{38}$ For Lanfranc's fame $c .1060$, see requests by Popes Nicholas II and Alexander II that he instruct their associates; Patrologia Latina 143:1349-50 and 149:1353 respectively.

${ }^{39}$ Lanfranc, Commentary on the Pauline Epistles, Patrologia Latina 150:163в: “[...] regulas artium saecularium [...] quae per singula exponerem, nisi imperitorum talium doctrinarum murmur timeretur."

${ }^{40} \mathrm{Ep}$, 56:164-67.
} 
Norman polemicists. ${ }^{41}$ In contrast to those, Anastasius and John did not compose full-length treatises on the subject, but, respectively, a short epistle and a meditative prayer. As such, their comments show that anti-intellectual rhetoric was an intrinsic feature of Norman polemic against Berengar and did not reflect some convention exclusive to more systematic discussions.

Anastasius wrote at the request of his letter's addressee, Abbot Gerald, perhaps of Saint-Vigorde-Cerisy. The text is not datable although its sketchiness has been taken as suggesting an early stage in the dispute, probably sometime in the $1050 \mathrm{~s} .{ }^{42}$ Anastasius relied exclusively on relevant quotations from authorities, such as Ambrose and Augustine. He sought neither to specify Berengar's error nor justify his own approach other than in a casual manner. Anastasius distanced himself from those who put up dialectical arguments and relished erudite expression. Employing the patristic motif of naming pagan authors, particularly Aristotle and Chrysippus, as bad influences, he denounced rationalistic reasoning about God as in the extract below. ${ }^{43}$

[...] I humbly ask that you be not astonished if you are not able here to weigh such ponderings as are babbled out by the Aristotelians or argued by Chrysippus's followers, or a creek running from the river of Tullian eloquence; but bear in mind that plainly do we pick fruits in the garden of Sacred Writ [...]. ${ }^{44}$

\footnotetext{
${ }^{41}$ These are Lanfranc, Durand of Troarn and Guitmund. For Durand's exposition, published $c .1054$, see Brian Stock, The Implications of Literacy: Written Language and Models of Interpretation in the Eleventh and Twelfth Centuries (Princeton: Princeton University Press, 1982), 290-95. Guitmund's work, datable to $1073 \times 1075$, is summarized by Vaillancourt, Lanfranc and Guitmund, 11-21.

${ }^{42}$ Mathieu Arnoux, "Un vénitien au Mont-Saint-Michel: Anastase, moine, ermite et confesseur († vers 1085)," Médiévales 14 (1995): 55-78, at 64.

${ }^{43}$ E.g. Gregory Nazianzen, Orationes, Patrologia Graeca 36:201C and Augustine, Contra Iulianum opus imperfectum, Patrologia Latina 45:1459.

${ }^{44}$ Patrologia Latina 149:436A: "[...] humiliter obsecro non mireris, si garrula Aristotelicorum vel Cripsippeorum argumenta trutinare, vel ex flumine Tullianae eloquentiae rivulum ducere, non perpendis: sed memento quia simpliciter fructus carpimus in divinae paginae hortulo [...]."
} 
John of Fécamp's so-called Confessio fidei, the final recension of his Confessio theologica, was a more sophisticated affair. A meditative treatise on approaching God through prayer, Confessio was one of the first works to resurrect theology as a contemplative category. ${ }^{45}$ It had an impact such that the meditative prayer, characterized by intense emotion and introspection, emerged as a fashionable genre in Normandy. Anselm's prayers and, as argued below, the Proslogion should be considered representatives of that tradition. ${ }^{46}$ John composed the first version of his work sometime between 1023 and 1028, when serving as prior of Fécamp. As abbot of the same house, he revised the work twice, first $c .1030$ and then, to renounce Berengar's teaching, c. $1050 .{ }^{47}$ The potpourri below comes from the final recension's anti-Berengarian polemic. John maintained that the rationalization of Christian mysteries was inappropriate. The final clause below, a quotation from Gregory the Great, was authoritative. ${ }^{48}$

One should admire [that mystery] and be in awe of it, not scrutinize it. [...] It must be received in faith, not examined or discovered by reason. [...] If it is a divine thing — nay, because it is such—far be it that something therein would be comprehended other than by God's inspiration and spiritually. [...] "Faith to which human reasoning supplies proof lacks merit." 49

\footnotetext{
45 The fullest commentary is Lauren Mancia, Emotional Monasticism: Affective Piety in the Eleventh-Century Monastery of John of Fécamp (Manchester: Manchester University Press, 2019), 18-153. For previous arguments about the work's authorship, see pp. 1-3 and 142 note 37.

${ }^{46}$ Mancia, Emotional Monasticism, 161-64; Brian McGuire, "John of Fécamp and Anselm of Bec: A New Language of Prayer," Prayer and Thought, 153-65.

${ }^{47}$ Mancia, Emotional Monasticism, 3 and 123-26.

${ }^{48}$ Gregory the Great, Homiliae in Evangelia, Patrologia Latina 76:1197c.

${ }^{49}$ Patrologia Latina 101:1087A-90A: "Magis venerandum est et pavendum, quam discutiendum. [...] Fide capiendum est, non ratione quaerendum, aut inveniendum. [...] Et si res divina est, imo quia ita est, absit ut aliquid ibi aliter, nisi divine et spiritualiter intelligatur. [...] 'Fides non habet meritum, cui humana ratio praebet experimentum."
} 
Gregory's pronouncement also encapsulates the standpoint of the full-length anti-Berengarian treatises of Norman authors. Lanfranc and Guitmund cited the passage to the same effect as John. ${ }^{50}$ While not employing the quotation, Durand of Troarn's treatise subscribed to the point. It asserted that faith's "incalculable mysteries" should be "revered rather than scrutinized." 51 The Norman polemicists agreed that Berengar abandoned faith by attempting to rationalize a Christian mystery.

Written commentary was part of what must have been a wider discourse in Normandy, conducted predominantly viva voce from the outset. "Wise men from the whole of Normandy" discussed Berengar's teaching in the conference convened by Duke William in $10505^{52}$ The impetus subsequently to combat Berengar in writing came often from private exchanges. Anastasius's letter was a commission from Abbot Gerald. Lanfranc wrote at the request of a former student..$^{53}$ Guitmund's treatise is a dialogue between himself and Brother Roger and may be a literary echo of actual conversations.$^{54}$ Frequent face-to-face discussions were surely a precondition for, and the result of, the fact that over a period of almost thirty years at least five commentaries on the subject were penned in Normandy. The cited writers certainly did not act in isolation from their communities. As monastic teachers and spiritual guides, they would have been obliged to warn their brethren of Berengar's shortcomings. We may safely assume, for

\footnotetext{
${ }^{50}$ Lanfranc, De corpore, Patrologia Latina 150:439C; Guitmund, De corporis et sanguinis Christi ueritate, Patrologia Latina 149:1439B; Vaillancourt, Lanfranc and Guitmund, 81 and 115 respectively.

${ }^{51}$ Durand, De corpore, Patrologia Latina 149:1400D: "Innumera sint Scripturae sacrae mysteria, quae revereri magis mortales quam scrutari oporteat."

52 Durand, De corpore, Patrologia Latina 149:1422A.

${ }^{53}$ The evidence comes from an inscription in Vatican, BAV, Pal. Lat. 482, fo. 43r.

${ }^{54}$ Vaillancourt, Lanfranc and Guitmund, 11.
} 
instance, that Lanfranc held conversations on the subject over the years in a variety of settings, ranging from private audiences to the classroom and formal chapter meetings. Nor did his installation as abbot of St Étienne at Caen in 1063 sever his ties with Bec. The latter provided the former, a new foundation, with the larger part of its initial fraternity. As a result, interaction between the two houses characterized their lives until at least the late $1080 \mathrm{~s} .{ }^{55}$ We may assume that the viewpoints in Lanfranc's De corpore et sanguine Domini did not fundamentally differ from those aired in his conversations at Bec, Caen, and elsewhere. These remarks, mutatis mutandis, apply to the other Norman polemicists whose related writings survive. Notably, each of them almost certainly had a first-hand link to the abbey of Bec, Anselm's home community. ${ }^{56}$ We lack direct evidence of that connection only for John of Fécamp. But he must have been a well-known and revered figure and author at Bec by virtue of his eminent role in the reformation of monastic life in Normandy. ${ }^{57}$ Anselm was, furthermore, connected to Fécamp circles via Archbishop Maurilius of Rouen, a monk of that house, whom he consulted at crucial points in his monastic career..$^{58}$

The witness of local synods, assemblies that were a key forum for doctrinal discussion, helps us understand how passionate the discussion of Berengar's teaching was in Normandy. In a synod held under Archbishop Maurilius of Rouen, either at Rouen in 1063 or at Lisieux in 1064, the delegates pronounced a formal denunciation of Berengar's Eucharistic doctrine. ${ }^{59}$ The formula

\footnotetext{
${ }^{55} \mathrm{Ep}, 19: 62,40: 118,65: 192$, and 121:356.

${ }^{56}$ For Guitmund, see Patrologia Latina 149:1449D; for Anastasius, Anselm's Ep, 3:14-15; for Durand, Paris, BnF, lat. 13905 , fo. $75 \mathrm{v}$, his entry in Bec's necrology.

${ }^{57}$ Lauren Mancia, "Praying with an Eleventh-Century Manuscript: A Case Study of Paris, BnF, MS lat. 13593," in Boundaries in the Medieval and Wider World: Essays in Honour of Paul Freedman, ed. Thomas Barton, Susan McDonough, Sara McDougall, and Matthew Wranovix (Turnhout: Brepols, 2018), 153-77, at 170-73.

${ }^{58}$ Eadmer, Vita Anselmi, 10 and 21.

${ }^{59}$ Herbert Schneider, Die Konzilordines des Früh- und Hochmittelalters, Monumenta Germaniae Historica: Ordines de celebrando concilio (Hanover: Hahn, 1996), 110-11 and 573.
} 
found its way into a liber pontificalis, a collection for conducting episcopal rites, which was compiled under John of Ivry, archbishop of Rouen 1069-79. The detail, which has escaped the attention of Berengarian scholarship, is of significance. John's liber pontificalis prescribed—and is our best evidence for- the rite of major ceremonies he conducted in his capacity as archbishop. This is to say that the Norman clergy were henceforth required to recite the antiBerengarian profession of faith at major ecclesiastical events over which the archbishop officiated. Unattested elsewhere, the practice was probably unique to the province of Rouen. The events in question included ordinations, synodal assemblies, and probably the dedications of new churches. John's years as archbishop saw three consecrations and synodal assemblies at least in $1069,1070,1072,1073,1074$, and $1078 .{ }^{60}$ Furthermore, John performed the dedication of Bec's new church in $1077 .{ }^{61}$ The anti-Berengarian creed is therefore likely have been recited at Bec at the time Anselm was working on the Proslogion. Official pronouncements on Berengar's teaching surely inspired derogatory face-to-face discussions. The fact that the delegates of a synod were obliged by law and custom to apprise their home communities of its decisions and discussions ensured that Berengar's errors were regularly spoken of in major churches. Finally, the context into which the Eucharistic profession was positioned in Rouen's liber pontificalis hints at great anxiety. The text immediately follows the creeds of the great ecumenical councils, so that the certification of allegiance to Catholic orthodoxy involved public denunciation of Berengar's teaching. The man was regarded as a threat of enormous proportions.

\footnotetext{
${ }^{60}$ Raymonde Foreville, "The Synod of the Province of Rouen in the Eleventh and Twelfth Centuries," in Church and Government in the Middle Ages: Essays presented to C. R. Cheney on his 70th birthday, ed. Christopher Brooke, David Luscombe, Geoffrey Martin, and Dorothy Owen (Cambridge: Cambridge University Press, 1976), 19-39, at 22 and 28.

${ }^{61}$ Orderic Vitalis, Historia ecclesiastica, ed. M. Chibnall, 6 vols., (Oxford: Oxford University Press, 1969-80), 3:10-13.
} 
The brethren of Bec were patently aware that Berengar had been the subject of conciliar condemnation. There survives first-hand testimony in a contemporary manuscript, Cambridge, Trinity College, B.16.44. The book is from Bec, from where it was transferred to England at some point during Lanfranc's archiepiscopate, as evidenced by a colophon. ${ }^{62}$ It carries a canon law collection known as Collectio Lanfranci. The title is a modern invention; the work's compiler is unknown, although the odds are that he was from Bec. ${ }^{63} \mathrm{He}$ drew almost entirely on the so-called Pseudo-Isidorian decretals, a ninth-century collection of papal letters and conciliar canons, the bulk of which were forgeries and purportedly from previous centuries. He divided the material into two sections, the first of which concerns us. This ends with three documents pertaining to the pope's Easter Synod of $1059 .{ }^{64}$ They stand out: contemporaneous with the Collectio Lanfranci, they date from several hundred years later than the other material. They were additions by the compiler. The final piece is Berengar's recantation of heresy at the synod. His condemnation was presented as the most recent step in the central history of Christian doctrine. As in Rouen's liber pontificalis, Berengar was taken with extreme seriousness at Bec.

Collectio Lanfranci was demonstrably being perused at Bec during the period under discussion. In a letter datable to $1070 \times$ August 1078 , Anselm discussed the matter of re-entry into clerical office after a lapse. He referred to two papal letters (of spurious origin), one which "the Blessed Pope Callixtus addressed to all bishops stationed within Gaul" and one which was from "the Blessed Gregory to Secundinus the recluse." ${ }^{65}$ Those two letters are found in Collectio

\footnotetext{
62 Trinity College, B.16.44, p. 405.

${ }^{63}$ Martin Brett, "The Collectio Lanfranci and its Competitors," in Intellectual Life in the Middle Ages: Essays Presented to Margaret Gibson, ed. Lesley Smith and Benedicta Ward (London: Bloomsbury Academic, 1992), 15774 , at $159-60$.

${ }^{64}$ Trinity College, B.16.44, pp. 209-10.

${ }^{65}$ Ep, 56:166-67.
} 
Lanfranci ${ }^{66}$ Because they are separated from each other by dozens of folia in that work, Anselm's recognition of them betrays careful study of it within his circle. The coincidence is underscored by the fact that elsewhere in his preserved writings, he very seldom refers explicitly to canonistic sources.

We may now return to the violent in-house assault on Anselm's drafts towards the Proslogion. To weigh the incident's proportions, one must bear in mind that Anselm held the office of prior at the time. In that capacity he ranked second in the house and oversaw its internal life. Stealing and smashing his writings constituted a serious breach of conduct, a denial of obedience, which could not go unpunished. Violent measures in correction were commonplace in the Benedictine tradition. If the party were ever caught, the penalty would have been severe. The culprit(s) must have been profoundly disturbed by the prior's work. The concern was certainly Anselm's rationalistic approach, the only aspect of the Proslogion that could have been considered threatening, as noted above. The assault on the Proslogion's drafts represented disapproval of argument by reason, which had also formed the basis of Lanfranc's and others' displeasure with the Monologion. ${ }^{67}$ Yet, the in-house violence attests to an anxiety too intense to have stemmed from previous censorious remarks alone, even if these had fanned the alarm about Anselm's method. Rather, the culprit(s) had fallen victim to the monastic exploitation of anti-intellectual rhetoric. The Berengarian controversy had whipped up such discourse within the circles to which Anselm belonged. In the province of Rouen, the unparalleled quantity of written polemics and the anti-Berengarian creed recited at major ecclesiastical events speak of sustained zeal. The former warned against reasoning about divine mysteries; the latter certified by implication that

${ }^{66}$ Trinity College, B.16.44, pp. 37-39 and 191-94.

${ }^{67}$ Gasper, "Envy, Jealousy," 46-47, 61, and 68. 
the perils of such inquiries were of the utmost gravity. Patently informed of Berengar's condemnation, formal and rhetorical, the party sabotaging Anselm's drafts was vulnerable to these fears.

\section{Epistemology and spirituality in the Proslogion}

Important for this discussion is the fact that upon publishing the Monologion, Anselm prepared himself for criticism. In the work's prologue he asserted that no novelty would be issued and that conclusions would comply with patristic writings, particularly Augustine's De Trinitate, even if these had not been explicitly cited ${ }^{68}$ These justifications proved insufficient and the work met with censure, as discussed above in Section I. The brutal measures taken at Bec to terminate his treatise in progress, the Proslogion, promised a harsher reception. In what follows, I use that threat as a hermeneutical key to read first the Proslogion's Chapter 1 and original title, Fides quaerens intellectum, and then its more rarely discussed latter half, Chapters 14-26, and its literary idiom. ${ }^{69}$ Some qualification is needed here: my commentary only operates within the parameters of exploring anti-intellectual rhetoric. No claim is made that readings propounded would be exclusive. The Proslogion is a masterpiece by a superb writer who engages readers in various ways, literarily, intellectually, and spiritually. It cannot be explained by invoking a single motif. Two arguments will be presented in relation to how Anselm sought to prime his readership. First, he weaved into the Proslogion an epistemological backbone to reassure parties apprehensive about rationalistic inquiry. Second, he furnished the work with an idiom which had previously appealed to his audiences: he made it read like a meditative prayer. I propose that

\footnotetext{
${ }^{68} \mathrm{SAO}, 1: 8$.

${ }^{69}$ The fullest commentary on Chapters 14-26 is Campbell, Rethinking, 473-97.
} 
these two devices were employed to distance the Proslogion from criticism of the rationalistic approach.

The Proslogion did not have a preface at first and its Chapter 1 served as an introduction. Subsequently entitled "A rousing of the mind to the contemplation of God," the chapter prepares the reader for a spiritual exercise..$^{70}$ The central theme is man's inability to view God, a focus which, I argue below, was a device to pre-empt potential criticism. Although Chapter 1's characterization of the contents to follow is not false, the impression conveyed is only part of the truth, in that Anselm's rationalistic approach receives no proper introduction. No mention of speculative reasoning is made, other than by implication at the very end. The passage in question, which is given below, was intended as a programmatic statement. Its reference to Anselm's rationalistic method is so vague that even an attentive reader is unlikely to grasp what will come next.

I do not try, Lord, to attain Your lofty heights, because my understanding is in no way equal to it. But I do desire to understand Your truth a little, that truth that my heart believes and loves. For I do not seek to understand so that I may believe; but I believe so that I may understand. For I believe this also, that "unless I believe I shall not understand." 71

These sentences owed much to Augustine, as has often been pointed out. The prime instance of such parallelism is the utterance "credo ut intelligam" in the penultimate sentence, echoing

${ }^{70}$ Major Works, 84; SAO, 1:97.

${ }^{71}$ Major Works, 87; SAO, 1:100. 
Augustine's instruction “crede ut intelligas." 72 Nonetheless, a contemporary dimension, previously undetected, can also be observed. The extract addresses a key methodological issue behind the Eucharistic controversy: to what extent was recourse to dialectical tools legitimate? The Proslogion's Chapter 1 insisted that Anselm operate with the fundamental proviso that faith precedes reason. He would never pursue an argument in a spirit of free inquiry if a departure from orthodoxy could ensue. Considering how profoundly his approach was imbued with dialectic, such assertions were surely expedient in the wake of the Berengarian controversy.

It was by deliberate emphasis that Anselm's epistemological statement ended Chapter 1. A grand finale by design, its last sentence was shaped as a creed ("Nam et hoc credo"). The sentence concluded with a well-known biblical quotation. The passage, adjusted to the first person, is Isaiah 7:9, as rendered in several Vetus Latina manuscripts, rather than derived from the Vulgate. The Vetus Latina variant was often quoted by Augustine, other Latin Fathers, and medieval authors. ${ }^{73}$ The exegesis ranged between two emphases. Reason led men away from God; or it was indispensable to those seeking him. ${ }^{74}$ John of Fécamp and Guitmund cited the passage in the former spirit, alleging that Berengar preferred reason to faith.$^{75}$ The citation in the Proslogion resonates with that same emphasis rather than the other one. As such, the work affirmed an epistemology seemingly compatible with the denunciation of Berengar's recourse to dialectic.

\footnotetext{
72 Augustine, Sermones, Patrologia Latina 38:255 and 258.

${ }^{73}$ The Cross Database Searchtool of the Brepolis site produces 164 hits from patristic and medieval writings.

${ }^{74}$ E.g. Augustine, Contra Iulianum, ii.1 and De libero arbitrio, ii.2.6, Patrologia Latina Patrologia 44:673 and 32:1243 respectively.

75 John of Fécamp, Confessio, Patrologia Latina 101:1090A; Guitmund, De corporis ueritate, Patrologia Latina 149:1441D, Vaillancourt, Lanfranc and Guitmund, 120.
} 
The Proslogion's original title, Fides quaerens intellectum, complements the scheme. That title is plainly an allusion to Chapter 1's finale, taking the words quaerere and intellectus from its penultimate sentence: "for I do not seek to understand so that I may believe; but I believe so that I may understand." As such, the title stresses fides, not intellectus. The title is an intrinsic part of Anselm's epistemological axiom, which emphasizes the subordination of human reasoning to faith. The title and Chapter 1 in concert assured the readers that unorthodox inquiries would not follow. The objective was to convince the reader of the validity of the work's approach before he or she would encounter the ontological argument and deductions flowing from it. The Proslogion, as circulated under its original title and without the subsequently inserted preface, underscored the limits of human reasoning conspicuously by way of a preamble.

The preamble's failure to introduce Anselm's rationalistic method of inquiry served a purpose. The Proslogion's discussion proper starts with the ontological argument, delivered in Chapters 2-4. Rationalistic considerations on God's attributes then follow, comprising Chapters 5-13. Chapter 14 is a turning point. It poses the question as to whether conclusions achieved by way of reasoning in previous chapters capture God. The response is in the negative: God has been seen "to some extent," but not "as [He is]" ("sicuti es"). Compelled by that conclusion, Chapter 15 reevaluates the ontological argument's famous premise that God is "something than which nothing greater can be thought." Anselm asserted that God is "not only that than which a greater cannot be thought, but [...] also something greater than can be thought." 76 The clause precluded any suggestion that God's existence could be domesticated with recourse to dialectic. ${ }^{77}$ The immediately following chapters elaborate on the subject of God's ineffability. God's light is too

\footnotetext{
${ }^{76}$ Major Works, 96; SAO, 1:112.
}

${ }^{77}$ Campbell, Rethinking, 483-84. 
bright for man to view (16); features that Creation shares with God such as beauty are ineffable in the latter (17); human reason cannot dissect God's unity (18). The emphasis then shifts to God's mysterious majesty. Chapters 19-22 argue that God's existence differs profoundly from all other existence. Chapter 23 identifies the supreme being as the triune Godhead. Chapters 2426, which close the work, discuss heavenly bliss, concluding that man cannot apprehend the divine. If assessed in epistemological terms, the Proslogion can be roughly characterized as pursuing two lines. While Chapters 2-13 and 19-23 seek to conceive of God by reasoning, Chapters 1, 14-18, and 24-26 maintain that such attempts will necessarily prove inadequate. The work opens and concludes with assertions that God is beyond the reach of human thought. That narrative structure stresses that the mystery of God remains inviolate.

The Proslogion's epistemological emphasis contrasts with more positive perspectives in the Monologion. This latter asserts that anyone ignorant of the Christian concepts of God and Creation "can, even if of average ability, convince themselves, to a large extent, of [their] truth." ${ }^{78}$ Such optimism permeates the whole Monologion. Even in a discussion on man facing God's ineffability, the stress is on the advantages of reasoning, as betrayed by the chapter headings "One comes closest to knowledge of the supreme essence through the rational mind" and "The mind itself is the image and mirror of the supreme being." 79 Had Anselm experienced an intellectual crisis during the period of a year or so between completing the Monologion and composing the Proslogion?

${ }^{78}$ Major Works, 11; SAO, 1:13.

${ }^{79}$ Major Works, 72, 73; SAO, 1:77. 
Nothing in his other treatises suggests any profound change of attitude. In the Cur Deus homo, published in 1098, he remarked briefly that human reasoning will never exhaust divine mysteries, certainly his standpoint at all times.$^{80}$ Nonetheless, he had Brother Boso, his interlocutor in that work, open their dialogue by asserting that not to seek to rationalize faith constituted an act of "negligentia." 81 A detailed discussion on Christian epistemology is found in the Epistola de incarnatione Verbi, completed $c .1095$. It contains an invective against Roscelin of Compiègne, who had claimed that his nominalistic trinitarian exposition was in agreement with Anselm's views. Irritated, Anselm resorted to a common anti-intellectual trope, used already in the patristic period: Roscelin and his ilk were "dialecticae haeretici." ${ }^{2}$ Roscelin's fault was a lack of appropriate preparation. It was the prerogative of those who believed according to the prescriptions of a monastic constitution "to study the logic of how [catholic faith] operates." That "ladder of faith" leading to intellectus was epitomized in Isaiah 7:9.83 Anselm's Christian intellectual was, unmistakably, a monk who had immersed himself in obedience and learning. His last treatise, De concordia praescientiae et praedestinationis et gratiae Dei cum libero arbitrio, completed in 1107, maintained that "if [a] conclusion is reached by straightforward reasoning and Scripture in no way contradicts it, [...] that conclusion is accepted as authorized by Scripture." ${ }^{84}$ In other words, all rationally cogent arguments that did not conflict with Scripture enjoyed sanction by scriptural authority even if they lacked scriptural substantiation. It would be hard to propound a more rationalistic position within the confines of catholic orthodoxy. These observations do not imply incoherence of thought between the Proslogion and Anselm's other

\footnotetext{
${ }^{80} S A O, 2: 50$.

${ }^{81} S A O, 2: 48$.

${ }^{82}$ See e.g. Patrologia Latina 45:1259 and 145:1017A and 1073D for Augustine and Peter Damian respectively.

${ }^{83}$ SAO, 2:7-9; "[...] quaerere rationem quomodo sit" (translation mine); "[...] fidei scalam [...]."

${ }^{84}$ Major Works, 460; SAO, 2:271-72. See Gasper, “Between Dialectic and Scripture,” 182-83.
} 
treatises. By analogy with Isaiah 7:9, their divergent epistemological emphases represented the two ends of the passage's traditional exegesis. Nonetheless, in that Anselm's other treatises are devoid of sustained epistemological concern, the Proslogion did constitute a digression.

The work also offers a contrast to his other treatises in that it reads like a meditative prayer. The assessment applies also to the Monologion; while it has a meditative aspect, that consists of short forays into the self, which are mainly exhortations to ponder some new subject. Significantly, the contemplative idiom came off more conspicuously in the Proslogion as circulated before Hugh of Lyon's intervention, as will shortly be discussed. At that stage, to quote Anselm's first critical editor, the Proslogion "was in the form of a prayer." 85

The Proslogion was a literary experiment, and one which Anselm did not care to revisit in his later treatises. Having observed an unusual effect, a historian should seek to establish an explanation. I propose that the prayer form was to entice and reassure audiences uncomfortable with the pure rationality at the Proslogion's core, the ontological argument. In terms of style, the Proslogion is remarkably similar to John of Fécamp's above-discussed Confessio fidei, but they differ from each other in method and intention. While Anselm rationalized faith, John was “a theorist of emotion," who quoted authorities extensively. ${ }^{86}$ Even so, the Confessio testified that Norman readerships were receptive to meditative theological inquiry. Furthermore, before the Monologion and Proslogion, Anselm had already circulated copies of his prayers, which soon won acclaim even beyond Normandy. Profusely praising one of them, Abbot Durand of La

${ }^{85}$ SAO's Stuttgart impression (1984), "Prolegomena seu ratio editionis," 64.

${ }^{86}$ Mancia, Emotional Monasticism, 164. 
Chaise-Dieu, a centre of monastic reform in south-central France, entreated him for more. ${ }^{87}$ Having established himself as a devotional author, Anselm sought to do the same as a scholarly one. The project did not begin well, as manifested by the criticism levelled against the Monologion. Then he devised a splendid line of reasoning, according to which God's existence was a logical necessity. The ensuing in-house assault on his drafts of that argument demonstrated that some of Anselm's own brethren regarded his reasoning as poisonous. Seriously violating monastic conduct, the attack intimated that reception after publication would hardly prove more favourable than the Monologion's. Anselm would have had good reason to present the Proslogion as a spiritual exploration rather than a learned tract. He decided to deliver the ontological argument as part of a meditative prayer, with the overarching emphasis that human rationality can never capture the mystery of God. I propose that such a design, unused in Anselm's other treatises, was intended to negotiate anti-intellectualist suspicions which had been so much incited by the Berengarian controversy.

After Hugh's apostolic injunction, Anselm wrote and published with confidence. He promoted the Monologion and Proslogion readily, demonstrating that he had no further reluctance about circulating them. ${ }^{88} \mathrm{He}$ also resumed his career as a theological author, as noted above. More relevant still are his supplements to the Proslogion: the preface, chapter headings, "Sumptum ex hoc libello," and his famous exchange with Gaunilo, all of which were subsequent to Hugh's intervention. I summarize these devices here by the probable order of their incorporation, the rationale for which derives from the evidence of the manuscripts. First, the six manuscripts representing provisional transmission under the title Fides quaerens intellectum lack these

\footnotetext{
${ }^{87} \mathrm{Ep}, 61: 180$.

${ }^{88}$ Ep, 99:290; SAO, 1:176, 190, and 2:20, 35.
} 
devices altogether. ${ }^{89}$ Secondly, Paris, BnF, lat. 564 and Graz, Universitätsbibliothek, 737, twelfth-century manuscripts from Fécamp and Seckau respectively, include the preface and chapter headings but lack the "Sumptum" and the Gaunilo exchange. The suggestion is that these last two were added later than the preface and chapter headings. Thirdly, Cambridge, Trinity College, B.1.37, from Salisbury cathedral and made in the early 1090s or so, transmits all the supplements with the exception of the Gaunilo exchange. On the evidence of that manuscript it has been proposed that the exchange was Anselm's last insertion to the Proslogion, made perhaps as late as $1092 .^{90}$

The preface encapsulates the Proslogion as a chain of conclusions proved by "one single argument that for its proof require[s] no other save itself." ${ }^{91}$ The chapter headings and the listing of them prime readers to perceive the text in a premeditated fashion. Emphasizing key conclusions, they highlight reasoning rather than prayer. It makes a remarkable difference to the text. Even readers familiar with the Proslogion-I assert from experience-pay more attention to its devotional aspect if they omit chapter headings altogether. For instance, when primed by the headings "That God truly exists" and "That God cannot be thought not to exist" of Chapters 2 and 3, one focuses on the ontological argument's distinct phases at the cost of the prayer at its opening and close. ${ }^{92}$ As for the "Sumptum," apparently a later insertion, it simply reproduces the ontological argument. As such it ensures that the Proslogion's rational core would not go unrecognized. By 1092, Gaunilo of Marmoutier, an otherwise unknown reader, rejected the ontological argument in exclusively rationalistic terms. Having obtained his comment, Anselm

\footnotetext{
${ }^{89}$ See note 23 above and SAO (1984), "Prolegomena," 64.

${ }^{90}$ Sharpe, "Anselm as author," 35; cf. Holopainen, Historical Study, 206.

${ }^{91}$ Major Works, 82; SAO 1:93.

${ }^{92}$ Major Works, 87-89; SAO, 1:101-4.
} 
appended it to the Proslogion together with his own response, which likewise operated from reason alone. To conclude, each of the supplements underscores the Proslogion's rationalistic aspect in one way or another. The implication is that Anselm considered the work's prayer-like idiom was failing to communicate its central substance perfectly. Furthermore, after Hugh's endorsement, he felt no need to continue to adjust the literary voice of his rationalistic exploration towards one of prayer.

Anselm's predicament had been resolved. Yet, even as archbishop of Canterbury, he wished to obtain authoritative endorsement for his rationalistic method. Exiled in Italy in 1098, he commended to Pope Urban II an unidentified treatise, taken to be Cur Deus homo in its critical edition. Anselm's short dedicatory note is about his theological method. He advised the resumption of the patristic endeavour to expound faith rationalistically. For "the logic ("ratio") of the truth is so copious and profound that it cannot be exhausted by mortals." In line with the above-discussed positivist exegesis of Isaiah 7:9, he assured that God encourages "us to pay more attention to understanding." Hence his own attempts "to arise to contemplate the logic of our beliefs." The dedication ended with the request that Urban inspect the work in question, implying papal endorsement of rationalistic theology. ${ }^{93}$ The manoeuvre resonates with Anselm's insight from the 1070s discussed above, that parties accepting no assertion "other than by the authority of Scripture" heeded the pope's judgements.

\footnotetext{
${ }^{93}$ Major Works, 260-61; SAO, 2:39-41.
} 